\title{
EFFECT OF CONJUGATED LINOLEIC ACID AND DIFFERENT TYPE OF DIETARY FAT ON SERUM LIPID PROFILE, LIVER ENZYMES ACTIVITY AND OXIDATIVE STRESS MARKERS IN WISTAR RATS
}

\author{
Magdalena Franczyk-Żarów ${ }^{l}$, Edyta Kuś ${ }^{2}$, Renata B. Kostogrys ${ }^{l}$ \\ ${ }^{1}$ Department of Human Nutrition, Faculty of Food Technology, University of Agriculture in Krakow, \\ Balicka 122, 30-149 Krakow, Poland \\ ${ }^{2}$ Jagiellonian Centre for Experimental Therapeutics (JCET), Bobrzyńskiego 14, 30-348 Krakow, Poland
}

\begin{abstract}
Background. Nutritional recommendations emphasize the need to limit consumption of saturated fatty acids and to increase the intake of polyunsaturated fatty acids in the prevention of non-communicable chronic diseases, particularly cardiovascular diseases. Among the fatty acids with health-related effects on the body, conjugated fatty acids are mentioned (i.e. CLA).

Objective. The current study was designed to determine the effects of conjugated linoleic acid (CLA) on serum lipid profile, glucose, liver enzymes activity (AST and ALT), malonic dialdehyde (MDA) as well as lipid hydroperoxide (LPO) concentrations in rats fed diet differing in type of dietary fat.

Material and methods. Male Wistar rats were divided into six groups and fed the following diets: control AIN-93G diet contained soybean oil $(\mathrm{O})$ and diets with modification of fat source: butter $(\mathrm{B})$ and margarine $(\mathrm{M})$. The experimental diets were supplemented with $1 \%$ of conjugated linoleic acid (O+CLA, B+CLA, M+CLA). After 21 days the blood was collected and lipid profile, glucose, liver enzymes, MDA as well as LPO were analyzed.

Results. The dietary treatments had no significant effect on the body weight and liver weight of the animals. The concentrations of total cholesterol (TC) and LDL+VLDL cholesterol were unchanged. Both experimental factors (fat source and CLA) had a significant influence on the TAG and HDL levels. Margarine (M) significantly increased the TAG concentration, whereas CLA had a significant impact on the TAG reduction (M+CLA). Glucose level was significantly decreased in all groups fed diets supplemented with CLA. Serum ALT significantly increased in all CLA groups. Fat source had statistically significant influence on the MDA concentration. The LPO level was significantly elevated in all CLA groups. There was statistically significant interaction of experimental factors (fat source and CLA supplementation) on LPO level.

Conclusions. Margarine had an adverse effect on the rat's lipid profile. However, in the group fed with margarine, the addition of CLA decreased the concentration of TAG. Regardless of the type of the dietary fat, CLA supplementation increased the level of LPO in the blood serum of animals.
\end{abstract}

Key words: conjugated linoleic acid, dietary fat, lipid profile, liver enzymes activity, oxidative stress markers, rats

\section{STRESZCZENIE}

Wprowadzenie. Zalecenia żywieniowe podkreślają potrzebę ograniczania spożycia nasyconych kwasów tłuszczowych i zwiększania spożycia wielonienasyconych kwasów tłuszczowych w prewencji przewlekłych chorób niezakaźnych, szczególnie chorób układu krążenia. Spośród kwasów tłuszczowych o prozdrowotnym oddziaływaniu na organizm wymienia się sprzężone kwasy tłuszczowe (tu: CLA).

Cel. Badanie miało na celu określenie wpływu sprzężonego kwasu linolowego (CLA) na profil lipidowy, aktywność enzymów wątrobowych (AST i ALT), dialdehyd malonowy (MDA) oraz stężenie wodoronadtlenku lipidów (LPO) w surowicy krwi szczurów żywionych dietami zawierającymi różne źródła tłuszczu.

Materiały i metody. Samce szczurów Wistar żywiono dietami AIN-93G o różnym źródle tłuszczu: olej sojowy (O), masło (B) i margaryna (M). Diety eksperymentalne uzupełniono 1\% dodatkiem CLA (O+CLA, B+CLA, M+CLA). Zwierzęta otrzymywały dietę oraz wodę ad libitum. Po 21 dniach doświadczenia w pobranej krwi wykonano analizy profilu lipidowego, glukozy, aktywności enzymów wątrobowych (AST i ALT), MDA oraz LPO.

Wyniki. Skład diet eksperymentalnych nie miał istotnego wpływu na masę ciała i masę wątroby zwierząt. Stężenia cholesterolu całkowitego (TC) i cholesterolu frakcji LDL + VLDL nie uległy zmianie. Zarówno źródło tłuszczu jak i CLA miały znaczący wpływ na poziomy TAG i frakcji HDL cholesterolu. Margaryna (M) istotnie zwiększała stężenie TAG, podczas gdy CLA obniżył

Corresponding author: Magdalena Franczyk-Żarów, Department of Human Nutrition, Faculty of Food Technology, University of Agriculture in Kraków, Balicka 122, 30-149 Kraków, Poland, phone: +48 1266248 33, Fax:+48 1266248 12, e-mail: magdalena.franczyk-zarow@urk.edu.pl

(C) Copyright by the National Institute of Public Health - National Institute of Hygiene 
istotnie stężenie TAG w grupie M+CLA. Poziom glukozy we wszystkich grupach, którym podawano diety z dodatkiem CLA, istotnie się zmniejszył. Aktywność ALT w surowicy istotnie wzrosła we wszystkich grupach z dodatkiem CLA. Źródło tłuszczu miało statystycznie istotny wpływ na stężenie MDA. Poziom LPO był istotnie podwyższony we wszystkich grupach CLA. Wykazano istotną statystycznie interakcję czynników eksperymentalnych (źródło tłuszczu i CLA) na poziom LPO.

Wnioski. Żywienie zwierząt dietą z dodatkiem margaryny miało niekorzystny wpływ na profil lipidowy szczurów. Natomiast w grupie żywionej margaryną dodatek CLA obniżył stężenie TAG. Bez względu na rodzaj spożywanego tłuszczu suplementacja CLA podniosła poziom LPO w surowicy krwi zwierząt.

Stowa kluczowe: sprzężony kwas linolowy, tluszcz w diecie, profil lipidowy, aktywność enzymów watrobowych, markery stresu oksydacyjnego, szczury

\section{INTRODUCTION}

Over the years there have been studied to examine the various components of dietary fat and their effect on serum lipids. Several studies reported serum lipid responses to butter, margarine or vegetable oils added to control diets. Moreover, the trans fatty acids resulting from the partial hydrogenation of vegetable oils and their replacement of the saturated fatty acids in many processed food have been reported to produce undesirable serum lipopotein profiles [19]. Additionally, it was shown that polyunsaturated fatty acids are effective in lowering serum cholesterol.

Conjugated linoleic acid (CLA) is a term that refers to a collection of positional and geometric isomers of linoleic acid (LA)- 18:2 n-6 with conjugated double bonds. This fatty acids are the natural food component occurring in the lipid fraction of meat, milk and other dairy products [13]. It has been largely demonstrated that CLA has positive effects in cancer $[2,3,7]$, cardiovascular disease $[1,22,28$, $30]$, diabetes [20, 23, 25] and obesity [6, 27, 31].

According to knowledge about oil, butter and margarine consumption on human health, the aim of this study was to determine the effect of diets with different fat sources and CLA on serum lipid profile, glucose, liver enzymes activity as well as oxidative stress markers in rats.

\section{MATERIAL AND METHODS}

\section{Animal and diets}

Male Wistar $(\mathrm{n}=36)$ rats, weighing about 100 $\mathrm{g}$ were housed during the experimental period of 21 days in an isolated room under conditions of controlled temperature, humidity and a $12 \mathrm{~h}$ lightdark cycle. After the adaptation period (5 days), the Wistar rats were divided into six groups $(\mathrm{n}=6)$ and fed purified base diet AIN-93G [24]. Modifications of diet consist in different fat source and supplementation with CLA as follows: O- soybean oil, B- butter, Msoft margarine, O+CLA- soybean oil and CLA, B + CLA - butter and CLA, M + CLA - margarine and CLA. The CLA oil (Luta-CLA ${ }^{\circledR}$ 60), obtained from BASF (Ludwigshafen, Germany) contained $600 \mathrm{~g}$ $\mathrm{CLA} / \mathrm{kg}$, with equal representation of two major CLA isomers (cis-9, trans-11 and trans-10, cis-12). The final composition of the diets is shown in Table 1. After 21 days of feeding rats were anesthetized with an ip injection of thiopental: $120-150 \mathrm{mg} / \mathrm{kg}$ (Biochemie; Vienna, Austria). All procedures involving animals were conducted according to the Guidelines for Animal Care and Treatment of the European Union and were approved by the Local Animal Ethics Commission.

Table 1. The composition of the experimental diets

\begin{tabular}{|c|c|c|c|c|c|c|}
\hline $\begin{array}{c}\text { DIETS * } \\
\text { INGREDIENTS }\end{array}$ & $\mathbf{O}$ & B & $\mathbf{M}$ & O+ CLA & $\mathbf{B}+\mathbf{C L A}$ & $\mathbf{M}+\mathbf{C L A}$ \\
\hline & \multicolumn{6}{|c|}{$\mathrm{g} / \mathrm{kg}$} \\
\hline Cornstarch & 532.486 & 532.486 & 532.486 & 532.486 & 532.486 & 532.486 \\
\hline Casein & 200 & 200 & 200 & 200 & 200 & 200 \\
\hline Sucrose & 100 & 100 & 100 & 100 & 100 & 100 \\
\hline Soybean oil & 70 & - & - & 53.33 & - & - \\
\hline Butter & - & 70 & - & - & 53.33 & - \\
\hline Soft Margarine & - & - & 70 & - & - & 53.33 \\
\hline Fibre & 50 & 50 & 50 & 50 & 50 & 50 \\
\hline Mineral mix & 35 & 35 & 35 & 35 & 35 & 35 \\
\hline Vitamin mix & 10 & 10 & 10 & 10 & 10 & 10 \\
\hline Choline bitartrate & 2.5 & 2.5 & 2.5 & 2.5 & 2.5 & 2.5 \\
\hline Tert-butylhydroquinone & 0.014 & 0.014 & 0.014 & 0.014 & 0.014 & 0.014 \\
\hline CLA $^{* *}$ & - & - & - & 16.67 & 16.67 & 16.67 \\
\hline
\end{tabular}

* O- oil diet: AIN-93G; B- butter diet: AIN-93G + butter; M- margarine diet: AIN-93G + margarine; O+CLA- oil diet supplemented in CLA: AIN-93G + 1\% CLA; B+CLA- butter diet supplemented in CLA: AIN-93G + 1\% CLA; M+CLA- margarine diet supplemented in CLA: AIN-93G + 1\% CLA.

${ }^{*}$ CLA - the CLA oil (Luta-CLA ${ }^{\circledR} 60$ ), obtained from BASF (Ludwigshafen, Germany) contained $600 \mathrm{~g} \mathrm{CLA} / \mathrm{kg}$, with equal representation of two major CLA isomers (cis-9, trans-11 and trans-10, cis-12). 


\section{Blood analysis}

Blood samples were taken from the left ventricle of the heart, collected into test tubes and centrifuged (4 $000 \mathrm{~g}, 10 \mathrm{~min}$ ) to obtain serum samples. Serum samples were analyzed using commercially available kits for total cholesterol (TC; Liquick Cor-Chol 60 no 2-204; Cormay, Lublin, Poland), triacylglycerols (TAG; Liquick Cor-TG 30 no 2-262; Cormay, Lublin, Poland) and HDL cholesterol (HDL; Liquick Cor-HDL no 2-181). LDL+VLDL level was calculated. Blood glucose concentrations were measured using an Accu-ChekActive glucosemeter (Roche DiagnosticsGmbH, Mannheim, Germany). Malonic dialdehyde (MDA; OXI-TEK TBARS Assay kit; Alexis Biochemicals, USA) and Lipid Hydroperoxide (LPO Assay kit No 705002, Cayman Chemical, Michigan, USA) were analyzed in rat's serum. Also theactivity of alanine aminotransferase (ALT) and aspartate aminotransferase (AST) in rat's serum were analyzed using commercially available kits (No A6624050, A6661-050 AlphaDiagnostics, Warszawa, Poland).

\section{Statistical analysis}

Results are expressed as means. The data were subjected to two-way analysis of variance (ANOVA) calculated by STATISTICA 13 package (StatSoft Inc., USA), followed by post-hoc Duncan's multiple range test. Statistical significance was considered to be $P \leq 0.05$.

\section{RESULTS}

Effects of CLA and different fat source on body and liver weight

The effect of dietary treatments on body and liver weight is shown in Table 2. There was no significant effect on body weight and liver weight of animals fed different diets. The lowest liver weight was observed in control group $(\mathrm{O})$, whereas the highest liver weight were in $\mathrm{B}+\mathrm{CLA}$ and $\mathrm{M}+\mathrm{CLA}$ groups.

Table 2. Effect of dietary treatments (fat source and/or CLA supplementation) on body weight and liver weight of Wistar rats.

\begin{tabular}{|c|c|c|c|c|c|c|c|c|c|c|}
\hline \multirow{2}{*}{$\begin{array}{l}\text { Body and liver } \\
\text { weights }\end{array}$} & \multirow{2}{*}{$\mathrm{O}$} & \multirow{2}{*}{$\mathrm{B}$} & \multirow{2}{*}{ M } & \multirow{2}{*}{$\mathrm{O}+\mathrm{CLA}$} & \multirow{2}{*}{$\mathrm{B}+\mathrm{CLA}$} & \multirow{2}{*}{$\mathrm{M}+\mathrm{CLA}$} & \multirow{2}{*}{ SEM } & \multicolumn{3}{|c|}{ Effect of: } \\
\hline & & & & & & & & Fat & CLA & Interaction \\
\hline Final body weight (BW) $[\mathrm{g}]$ & 331.55 & 347.81 & 344.92 & 324.63 & 323.78 & 315.53 & 6.303 & 0.882 & 0.131 & 0.768 \\
\hline Body weight gain $[\mathrm{g}]$ & 192.15 & 211.64 & 209.75 & 187.96 & 187.28 & 179.53 & 6.528 & 0.852 & 0.156 & 0.718 \\
\hline Liver weight/ 100g BW [g] & 3.76 & 3.97 & 3.96 & 3.95 & 4.16 & 4.16 & 0.052 & 0.998 & 0.173 & 0.064 \\
\hline
\end{tabular}

Effects of CLA and different fat source on lipid profile

The effect of dietary treatments on lipid profile is shown in Table 3. In our experiment there was no statistically significant influence of experimental factors (fat source and CLA supplementation) on the TC and LDL+VLDL levels. However, both experimental factors (fat source and CLA) had a significant influence on the TAG and HDL levels.
The highest level of HDL was recorded in the group fed butter (B). Addition of CLA to butter as well as margarine groups significantly decreased the HDL cholesterol concentration. Margarine diet significantly increased triacylglycerol level in rats compared to other groups. At the same time, CLA supplementation decreased triacylglycerol level in M+CLA rats compared to margarine group.

Table 3. Effect of dietary treatments (fat source and/or CLA supplementation) on serum lipid profile in Wistar rats

\begin{tabular}{|c|c|c|c|c|c|c|c|c|c|c|}
\hline \multirow{2}{*}{ Serum lipid profile } & \multirow{2}{*}{$\mathrm{O}$} & \multirow{2}{*}{ B } & \multirow{2}{*}{ M } & \multirow{2}{*}{$\mathrm{O}+\mathrm{CLA}$} & \multirow{2}{*}{$\mathrm{B}+\mathrm{CLA}$} & \multirow{2}{*}{$\mathrm{M}+\mathrm{CLA}$} & \multirow{2}{*}{ SEM } & \multicolumn{3}{|c|}{ Effect of: } \\
\hline & & & & & & & & Fat & CLA & Interaction \\
\hline $\mathrm{TC}[\mathrm{mmol} / \mathrm{L}]$ & 1.61 & 1.89 & 1.80 & 1.46 & 1.58 & 1.72 & 0.051 & 0.130 & 0.070 & 0.595 \\
\hline TAG [mmol/L] & 2.07 & 1.96 & 2.73 & 1.55 & 1.33 & 1.81 & 0.110 & 0.017 & 0.000 & 0.634 \\
\hline $\mathrm{HDL}[\mathrm{mmol} / \mathrm{L}]$ & 1.03 & 1.43 & 1.28 & 0.91 & 0.98 & 0.95 & 0.045 & 0.019 & 0.000 & 0.113 \\
\hline $\mathrm{LDL}+\mathrm{VLDL}[\mathrm{mmol} / \mathrm{L}]$ & 0.65 & 0.46 & 0.55 & 0.54 & 0.60 & 0.77 & 0.040 & 0.425 & 0.294 & 0.238 \\
\hline
\end{tabular}

Effects of CLA and different fat source on glucose concentration

Dietary treatments affected the glucose concentration (Table 4). Glucose level was significantly decreased in all groups fed diets supplemented with CLA compared to those without supplementation. The significant difference was observed in rats administered O+CLA treatment compared to those received control $(\mathrm{O})$ diet .
Effects of CLA and different fat source on liver enzymes (AST and ALT) activity

The composition of experimental diets did not affect the serum AST activity (Table 4). However, the serum ALT significantly increased in all experimental groups after CLA supplementation. 
Table 4. Effect of dietary treatments (fat source and/or CLA supplementation) on serum glucose, AST and ALT activity, MDA and LPO concentrations in Wistar rats

\begin{tabular}{|c|c|c|c|c|c|c|c|c|c|c|}
\hline \multirow{2}{*}{ Serum } & \multirow{2}{*}{$\mathrm{O}$} & \multirow{2}{*}{ B } & \multirow{2}{*}{ M } & \multirow{2}{*}{$\mathrm{O}+\mathrm{CLA}$} & \multirow{2}{*}{$\mathrm{B}+\mathrm{CLA}$} & \multirow{2}{*}{$\mathrm{M}+\mathrm{CLA}$} & \multirow{2}{*}{ SEM } & \multicolumn{3}{|c|}{ Effect of: } \\
\hline & & & & & & & & Fat & CLA & Interaction \\
\hline Glucose [mg/dl] & 139.00 & 141.17 & 134.33 & 126.80 & 132.00 & 131.67 & 1.632 & 0.541 & 0.014 & 0.446 \\
\hline AST [U/I] & 69.84 & 50.49 & 55.14 & 55.87 & 72.75 & 54.71 & 4.246 & 0.725 & 0.764 & 0.241 \\
\hline ALT [U/I] & 19.06 & 25.17 & 26.48 & 24.88 & 35.07 & 31.43 & 1.586 & 0.058 & 0.023 & 0.757 \\
\hline MDA [nmol/ml] & 14.20 & 14.82 & 17.88 & 14.37 & 16.63 & 23.27 & 1.056 & 0.036 & 0.222 & 0.548 \\
\hline LPO [nmol/ml] & 26.06 & 27.04 & 42.48 & 67.32 & 85.95 & 58.38 & 4.245 & 0.237 & 0.000 & 0.003 \\
\hline
\end{tabular}

Effects of CLA and different fat source on oxidative stress markers (MDA and LPO) concentrations

CLA supplementation had no statistically significant effect on malonic dialdehyde concentration in rat's serum (Table 4). However, fat source had statistically significant influence on the MDA concentration. The lipid hydroperoxide level was significantly elevated in all CLA groups. The highest level of LPO was in the B+CLA group. In our experiment there was statistically significant interaction of experimental factors (fat source and CLA supplementation) on LPO level.

\section{DISCUSSION}

Various components of dietary fat and their effect on serum lipids are investigated. Dietary fat has an essential role in modulating immune and inflammatory responses. Both quantity and quality of fats have shown to affect these processes [13]. The type and degree of fatty acid unsaturation has also shown to affect immune and inflammatory responses [3]. Estimates for the daily consumption of margarine and butter are: in the United States - 11 and $6 \mathrm{~g} /$ person, respectively, in the Netherlands: 22 and $3 \mathrm{~g} /$ person, and in the Great Britain: 12 and $7 \mathrm{~g} /$ person [12]. Recommendations to reduce the risk of cardiovascular disease usually stress the importance of reducing intake of SFAs. In practical terms, this advice frequently implies restricting the intake of products rich in SFAs and cholesterol, such as butter, and replacing them in part with equivalent products lower in cholesterol and SFAs, but higher in unsaturated fatty acids, such as margarines. Over the past years, evidence has shown that, in addition to SFAs, trans unsaturated fatty acids (TFAs) also raise plasma total cholesterol and LDL cholesterol and may lower plasma HDL cholesterol concentrations. Some, but not all, studies indicated that high intakes of TFAs increase the risk of cardiovascular disease, which agrees with the observed effects of TFAs on blood lipids.

Therefore, the issue arises as to whether there are benefits to replacing a product rich in SFAs, such as butter, with a product lower in SFAs but higher in cis- and TFAs, such as margarine. It is now feasible to manufacture margarines that have no TFAs and/or have high amounts of unsaturated fatty acids without major increases in SFAs. In nutrition recommendations there are advices telling us that our goal is to limit intake of SFAs and to avoid TFAs altogether.

There are many studies showing positive effects of CLA as a bioactive ingredient. Up to now, there was no study examined the effects of CLA supplementation in diets containing different fat sources. Therefore, the aim of the present study was to determine effects of CLA and common sources of dietary fat (soybean oil, butter and margarine) on serum lipid profile, glucose and liver enzymes activity and oxidative stress markers in rats.

In our study there was no statistically significant influence of fat source on the TC and LDL+VLDL levels. However, it had a significant influence on the TAG and HDL levels. The highest level of HDL was recorded in the group fed butter (B). No effect on plasma lipoproteins was shown in growing pigs fed diets containing unsaturated plant fatty acids compared to pigs fed diet with saturated animal fat [18]. In contrast to the above findings, Wood et al. (1993) showed that total serum cholesterol levels were significantly higher in butter received group but significantly lower in soft margarine patients relative to baseline diet. There were no changes in TG content among dietary groups [32]. In contrast to our findings, Dorfman at al. (2005) showed, that in hamster fed butter, the level of TG increased more than in margarine group compared to soybean oil. However, the aoric lesion surface in margarine group was the highest $(0.84 \%)$ and it was double then soybean and butter group (0.4 vs $0.36 \%$ ) [5]. In Milewska et al. (2007) study it was shown that cholesterol enriched diets differing in dietary fat type (butter, margarine with stanols, margarine with rapeseed oil and sunflower oil) excluding diet containing margarine with stanols, had hypercholesterolemic effects on Wistar rats [21].

In the last years, attempts have been made to enrich animal-derived foods in CLA isomers through animal nutrition strategies (CLA-enriched milk, butter, cheese). In addition to natural foodstuff, dietary CLA supplements can also contribute to CLA intake in humans. In our study addition of CLA to butter 
as well as margarine groups significantly decreased the HDL cholesterol concentration. However, CLA supplementation decreased triacylglycerol level in $\mathrm{M}+\mathrm{CLA}$ rats compared to margarine group.

In human study, dietary treatment of CLA enriched butter resulted in a significant reduction in TC level compared to diet without CLA, while there were no differences in TG level between experimental groups [4]. Similar results have been presented by Lock et al. (2005) where hamsters fed butter naturally enriched in CLA had significant lower TC and TG concentration compared to animals fed no CLA diet [17]. Additionally, Franczyk-Żarów et al. (2008) shown, that CLA-enriched eggs exerted an anti-inflammatory effect more effectively than CLA-supplemented eggs in apoE/LDLR ${ }^{-/}$mice [8]. However, effect of CLA supplementations produced equivocal results. Conjugated linoleic acid decreased serum triacyloglycerol and changed fatty acid composition in rat's liver [16]. Kostogrys et al (2012) do not support the notion that CLA isomer supplementations to the oil or margarine possess anti-atherosclerotic effect [14, 15]. Moreover, Franczyk-Żarów et al. (2015) shown, that margarine supplemented with CLA significantly increased liver weight and induced steatosis in apoE/ $\mathrm{LDLR}^{-/}$mice, but CLnA supplementation alleviated the liver steatosis and affected the expression of lipid metabolism genes [9].

In our experiment CLA decreased glucose concentration. The discussion concerning antidiabetic effects of CLA is controversial. An experiment using Zucker diabetic fatty rats showed a normalization of impaired glucose tolerance and improved hyperinsulinemia induced by CLA [11]. A recent study showed inverse effects. C57BL/6J mice fed a CLAenriched diet developed a state resembling diabetes, with a marked insulin resistance (hyperinsulinemia) [29]. Also, in studies of Halade et al. (2010) the fasting serum glucose concentration was significantly increased in CLA-fed mice compared to the Control groups [10].

In our study serum ALT activity significantly increased in all experimental groups after CLA supplementation. The same effect observed Liu et al. (2012) in hamsters which presented elevated $(\mathrm{p}<0.05)$ ALT levels after feeding 2\% and 3\% t10,c12 CLA isomers. They concluded that a diet enriched with more than $2 \%$ t10, c12 led to liver malfunction and poses unfavorable changes on plasma lipid profiles [25]. Also in study of Kim et al. (2010) there was a prominent increase in ALT levels in high-fat-dietinduced obese $\mathrm{C} 57 \mathrm{BL} / 6 \mathrm{~J}$ mice that received esterified and free forms of CLA [21]. Moreover, dietary t10, c12 CLA induces a severe hepatic steatosis in mice with a more muted response in other species [41]. In contrast, dietary CLA did not affect serum aspartate aminotransferase (AST) or alanine aminotransferase (ALT) activities after a partial hepatectomy (PH) in Sprague-Dawley rats [14]. Additionally, conjugated linoleic acid supplement or foods enriched with CLA was associated with a significantly increased circulating AST without any significant effect on alkaline phosphatase (ALP) and ALT levels in human studies [31].

In our experiment fat source had statistically significant influence on the MDA concentration. Santos-Zago et al. (2007) showed that CLA reduced MDA and thus reduces oxidation for the group that received CLA as compared to the control group [26]. The reactive aldehydes like malondialdehyde (MDA) - decomposition products of lipid peroxides, are used as reliable indicators of lipid peroxidation. Lipid peroxidation is a well-characterized consequence of oxidative stress and leads to further cell and tissue damage. In several studies it was shown that CLA regulates lipid metabolism in various tissues by modulating lipid oxidation, lipolysis and de novo lipogenesis [6].

In our study the lipid hydroperoxide (LPO) level was significantly elevated in all CLA groups. In paper by Kilian et al. [19] in order to evaluate the impact of dietary LA and CLA on liver metastasis and lipidperoxidation (LPO) Syrian hamsters were BOP-induced pancreatic cancer. SOD activity and lipid peroxidation were increased in liver metastases [19]. Furthermore both diets decreased the activity of glutathion peroxidase and increased the level of lipid peroxidation in pancreatic intratumoral tissue [18]. Diniz et al. [6] concluded that CLA may be disadvantageous because it can lead to oxidative stress and dyslipidemic profile. Moreover, CLA accelerates the decomposition of storage lipids in WAT and the clearance of serum non-esterified fatty acid levels, resulting in lipid peroxidation and a morphological change in the liver [44]. In the contrary, the antioxidative effect of CLA was examined by Kim et al. (2005) by determining lipid peroxidation and antioxidative enzyme activities. Male Sprague-Dawley rats were fed diets: normal diet, vitamin E-deficient control diet, 0.5\% CLA vitamin E-deficient diet, or 1.5\% CLA vitamin E-deficient diet for $5 \mathrm{wk}$. Dietary CLA reduced lipid peroxidation by increasing oxidative stability in rats [20].

\section{CONCLUSIONS}

1. Margarine had an adverse effect on the rat's lipid profile.

2. The addition of CLA decreased the concentration of TAG in the group fed with margarine.

3. Regardless of the type of the dietary fat, CLA supplementation increased the level of LPO in the blood serum of animals. 


\section{Conflict of interest}

The authors declare no conflict of interest.

\section{REFERENCES}

1. Arbonés-Mainar J.M., Navarro M.A., Acín S., Guzmán M.A., Arnal C., Surra J.C., Carnicer R., Roche H.M., Osada J.: Trans-10, cis-12- and cis-9, trans-11-Conjugated Linoleic Acid Isomers Selectively Modify HDL-Apolipoprotein Composition in Apolipoprotein E Knockout Mice. J. Nutr. 2006; 136: 353-359.

2. Belury M.A.: Inhibition of carcinogenesis by conjugated linoleic acid: potential mechanisms of action. J. Nutr. 2002;132: 2995-2998.

3. Calder P.C.: Fat chance immunomodulation. Immunology Today. 1998; 19: 244-247.

4. Cho H.J., Kim E.J., Lim S.S., Kim M.K., Sung M.K., Kim J.S., Park J.H.Y.: Trans-10,cis-12, not cis-9,trans-11, conjugated linoleic acid inhibits G1-S progression in HT-29 human colon cancer cells. J. Nutr. 2006; 136: 893-898.

5. Desroches S., Chouinard P.Y., Galibois I., Corneau L., Delisle J., Lamarche B., Couture P., Bergeron N.: Lack of effect of dietary conjugated linoleic acids naturally incorporated into butter on the lipid profile and body composition of overweight and obese men. Am. J. Clin. Nutr. 2005; 82: 309-319.

6. Diniz Y.S., Santos P.P., Assalin H.B., Souza G.A., Rocha K.K., Ebaid G.M., Seiva F.R., Amauchi J.F., Novelli Filho J.L., Novelli E.L.: Conjugated linoleic acid and cardiac health: oxidative stress and energetic metabolism in standard and sucrose-rich diets. Eur. J. Pharmacol. 2008; 579: 318-325.

7. Dorfman S.E., Wang S., Vega-López S., Jauhiainen M., Lichtenstein A.H.: Dietary Fatty Acids and Cholesterol Differentially Modulate HDL Cholesterol Metabolism in Golden-Syrian Hamsters. J. Nutr. 2005; 135: 492498.

8. Evans M., Brown J., McIntosh M.: Isomer-specific effects of conjugated linoleic acid (CLA) on adiposity and lipid metabolism. J. Nutr. Biochem. 2002; 13: 508-516.

9. Field C.J., Schley P.D.: Evidence for potential mechanisms for the effect of conjugated linoleic acid on tumor metabolism and immune function: lessons from n-3 fatty acids. Am. J. Clin. Nutr. 2004; 79: 1190S-1198S.

10. Franczyk-Żarów M., Czyżyńska I., Drahun A., Maślak E., Chtopicki S., Kostogrys R.B.: Margarine supplemented with conjugated linolenic acid (CLnA) has no effect on atherosclerosis but alleviates the liver steatosis and affects the expression of lipid metabolism genes in apoE/LDLR ${ }^{-/}$mice. Eur. J. Lipid Sci. Technol. 2015; 117: 589-600.

11. Franczyk-Żarów M., Kostogrys R.B., Szymczyk B., Jawień J., Gajda M., Cichocki T., Wojnar L., Chłopicki S., Pisulewski P.: Functional effects of eggs, naturally enriched with conjugated linoleic acid (CLA), on the blood lipid profile, development of atherosclerosis and composition of atherosclerotic plaque in apolipoprotein $\mathrm{E}$ and low density lipoprotein receptor double-knockout mice (apoE/LDLR ${ }^{-/}$). Br. J. Nutr. 2008; 99: 49-58.
12. Halade G., Rahman M., Fernandes G.: Differential effects of conjugated linoleic acid isomers in insulin-resistant female C57B1/6J mice. J. Nutr. Biochem. 2010; 4: 332-337.

13. Han S.N., Leka L.S., Lichtenstein A.H., Ausman L.M., Schaefer E.J., Meydani S.N.: Effect of hydrogenated and saturated, relative to polyunsaturated, fat on immune and inflammatory responses of adults with moderate hypercholesterolemia. J. Lipid Res. 2002; 43: 445-452.

14. Hirao A., Yamasaki M., Chujo H., Koyanagi N., Kanouchi H., Yasuda S., Matsuo A., Nishida E., Rikimaru T., Tsujita E., Shimada M., Maehara Y., Tachibana H., Yamada K.: Effect of dietary conjugated linoleic acid on liver regeneration after a partial hepatectomy in rats. J. Nutr. Sci. Vitaminol. 2004; 50: 9-12.

15. Houseknecht K.L., Vandenheuvel J.P., Moyacamarena S.Y., Portocarrero C.P., Peck L.W., Nickel K.P., Belury M.A.: Dietary conjugated linoleic acid normalizes impaired glucose tolerance in the sucker diabetic fatty fa/fa rat. Biochem. Biophys. Res. Commun. 1998; 244: 678-682.

16. Judd J.T., Baer D.J., Clevidence B.A., Muesing R.A., Chen S.C., Weststrate J.A., Meijer G.W., Wittes J., Lichtenstein A.H., Vilella-Bach M., Schaefer E.J.: Effects of margarine compared with those of butter on blood lipid profiles related to cardiovascular disease risk factors in normolipemic adults fed controlled diets. Am. J. Clin. Nutr. 1998; 68: 768-777.

17. Kennedy A., Martinem K., Schmidt S., Mandrup S., LaPoint K., McIntosh M.: Antiobesity mechanisms of action of conjugated linoleic acid. J. Nutr. Biochem. 2010; 3: 171-179.

18. Kilian M., Mautsch I., Gregor J.I., Heinichen D., Jacobi C.A., Schimke I., Guski H., Müller J.M., Wenger F.A.: Influence of conjugated and conventional linoleic acid on tumor growth and lipid peroxidation in pancreatic adenocarcinoma in hamster. Prostaglandins, Leukotrien es and Essential Fatty Acids. 2003; 69: 67-72.

19. Kilian M., Mautsch I., Gregor J.I., Stahlknecht P., Jacobi C.A., Schimke I., Guski H., Wenger F.A.: Influence of conjugated vs. conventional linoleic acid on liver metastasis and hepatic lipidperoxidation in BOP-induced pancreatic cancer in Syrian hamster. Prostaglandins, Le ukotrienes and Essential Fatty Acids 2002; 67: 223-228.

20. Kim H.K., Kim S.R., Ahn J.Y., Cho I.J., Yoon C.S., Ha T.Y: Dietary conjugated linoleic acid reduces lipid peroxidation by increasing oxidative stability in rats. J. Nutr. Sci. Vitaminol. 2005; 51: 8-15.

21. Kim J.H., Pan J.H., Park H.G., Yoon H.G., Kwon O.J., Kim T.W., Shin D.H., Kim Y.J.: Functional comparison of esterified and free forms of conjugated linoleic acid in high-fat-diet-induced obese C57BL/6J mice. J. Agric. Food Chem. 2010; 58: 11441-11447.

22. Kostogrys R.B., Franczyk-Żarow M., Maślak E., Gajda M., Mateuszuk E., Chłopicki S.: Margarine supplemented with t10c12 CLA isomers decreased SMA in atherosclerosis plaque and induced steatosis in Apolipoprotein E and Low-Density Lipoprotein Receptor Doubleknockout mice $\left(\right.$ ApoE/LDLR ${ }^{-/}$). J. Nutr. Health Aging 2012; 16: 482-490. 
23. Kostogrys R.B., Maślak E., Franczyk-Żarów M., Gajda M., Chtopicki S.: Effects of trans-10,cis-12 and cis9,trans-11 CLA on atherosclerosis in apoE/LDLR ${ }^{-/-}$mice. The European J. Lipid Sci.Technol. 2011; 113: 572-583.

24. Kostogrys R.B., Pisulewski P.M.: Conjugated linoleic acid decreased serum triacyloglycerol and changed fatty acid composition in rat's liver. J. Anim. Feed Sci. 2010; 19: 484-494.

25. Liu X., Joseph S.V., Wakefield A.P., Aukema H.M., Jones P.J.: High dose trans-10, cis-12 CLA increases lean body mass in hamsters, but elevates levels of plasma lipids and liver enzyme biomarkers. Lipids. 2012; 47: 39-46.

26. Lock A.L., Horne A.M., Bauman D.E. Salter A.M.: Butter Naturally Enriched in Conjugated Linoleic Acid and Vaccenic Acid Alters Tissue Fatty Acids and Improves the Plasma Lipoprotein Profile in CholesterolFed Hamsters. J. Nutr. 2005; 135: 1934-1939.

27. Luhman C.M., Faidley T.D. Beitz R.C.: Postprandial lipoprotein composition in pigs fed diets differing in type and amount of dietary fat. J. Nutr. 1992; 122: 120-127.

28. Mensink R.P., Katan M.B.: Effect of dietary trans fatty acids on high-density and low-density lipoprotein cholesterol levels in healthy subjects. N. Engl. J. Med. 1990; 323: 439-445.

29. Mersmann H.J.: Mechanism for conjugated linoleic acid-mediated reduction In fat deposition. J. Anim. Sci. 2002; 80 (E. Suppl. 2): E126-E134.

30. Milewska M., Sińska B., Gromadzka-Ostrowska J.: Diety hipercholesterolemiczne zawierające różne tłuszcze spożywcze a lipidogram osocza szczurów. [Hypercholesterolemic diets containing different common fats and rats plasma lipids]. Rocz Panstw Zakl Hig 2007; 58: 15-21 (in Polish).

31. Mirzaii S., Mansourian M., Derakhshandeh-Rishehri S.M., Kelishadi R., Heidari-Beni M.: Association of conjugated linoleic acid consumption and liver enzymes in human studies: A systematic review and meta-analysis of randomized controlled clinical trials. Nutrition. 2016; 32: 166-173.

32. Noone E.J., Roche H.M., Nugent A.P., Gibney M.J.: The effect of dietary supplementation using isomeric blends of conjugated linoleic acid on lipid metabolism in healthy human subjects. Br. J. Nutr. 2002; 88: 243-251.

33. Noto A., Zahradka P., Ryz N.R., Yurkova N., Xie X.P., Taylor C.G.: Dietary conjugated linoleic acid preserves pancreatic function and reduces inflammatory markers in obese, insulin-resistant rats. Metabolism - Clinical and Experimental, 2007; 56: 142-151.

34. Reeves P.G., Nielsen F.H., Fahey G.C.: AIN-93 purified diets for laboratory rodents: final report of the American Institute of Nutrition ad hoc writing committee on the reformulation of the AIN-76A rodent diet. J. Nutr. 1993, 123(11): 1939-1951.
35. Ryder J.W., Portocarrero C.P., Song X.M., Cui L., Yu M., Combatsiaris T., Galuska D., Bauman D.E., Barbano D.M., Charron M.J., Zierath J.R., Houseknecht K.L.: Isomer-specific antidiabetic properties of conjugated linoleic acid - Improved glucose tolerance, skeletal muscle insulin action, and UCP-2 gene expression. Diabetes. 2001; 50: 1149-1157.

36. Santos-Zago L.F., Botelho A.P., de Oliveira A.C.: Supplementation with commercial mixtures of conjugated linoleic acid in association with vitamin $\mathrm{E}$ and the process of lipid autoxidation in rats. Lipids. 2007; 42: 845-854.

37. Terpstra A.H., Javadi M., Beynen A.C., Kocsis S., Lankhorst A.E., Lemmens A.G., Mohede I.C.: Dietary conjugated linoleic acids as free fatty acids and triacylglycerols similarly affect body composition and energy balance in mice. J. Nutr. 2003; 133: 3181-3186.

38. Tricon S., Burdge G.C., Kew S., Banerjee T., Russell J.J., Jones E.L., Grimble R.F., Williams C.M., Yaqoob P., Calder P.C.: Opposing effects of cis-9, trans-11 and trans-10,cis-12 conjugated linoleic acid on blood lipids in healthy humans. Am. J. Clin. Nutr. 2004; 80: 614-620.

39. Tsuboyama-Kasaoka N., Takahashi M., Tanemura K., Kim H.J., Tsuyoshi T., Okuyama H., Kasai M., Ikemoto S., Ezaki O.: Conjugated linoleic acid supplementation reduces adipose tissue by apoptosis and develops lipodystrophy in mice. Diabetes. 2000; 49: 1534-1542.

40. Valeille K., Gripois D., Blouquit M.F., Souidi M., Riottot M., Bouthegourd J.C., Serougne C., Martin J.C.: Lipid atherogenic risk markers can be more favourably influenced by the cis- 9 trans-11-octadecadienoate isomer than a conjugated linoleic acid mixture or fish oil in hamsters. Br. J. Nutr. 2004; 91: 191-199.

41. Vyas D., Kadegowda A.K., Erdman R.A.: Dietary conjugated linoleic Acid and hepatic steatosis: species-specific effects on liver and adipose lipid metabolism and gene expression. J. Nutr. Metabol. 2012: 932928.

42. Wang Y., Jones P.J.H.: The role of conjugated linoleic acid in human health. Dietary conjugated linoleic acid and body composition. Am. J Clin. Nutr. 2004; 79: 1153S-1158S.

43. Wood R., Kubena K., O’Brien B., Tseng S., Martin G.: Effect of butter, mono- and polyunsaturated fatty acidenriched butter, trans fatty acid margarine, and zero trans fatty acid margarine on serum lipids and lipoproteins in healthy men. J. Lipid Res. 1993; 34: 1-11.

44. Yamasaki M., Mansho K., Mishima H., Kimura G., Sasaki M., Kasai M., Tachibana H., Yamada K.: Effect of dietary conjugated linoleic acid on lipid peroxidation and histological change in rat liver tissues. J. Agric. Food Chem. 2000; 48: 6367-6371.

Received: 28.10.2018

Accepted: 03.01.2019

This article is available in Open Access model and licensed under a Creative Commons Attribution-Non Commercial 3.0.Poland License (CC-BY-NC) available at: http://creativecommons.org/licenses/by-nc/3.0/pl/deed.en 